\title{
NATO AND WESTERN BALKANS: STILL UNFINISHED BUSINESS
}

\author{
Stojan Slaveski, PhD \\ European Universiity, Skopje \\ E-mail: sslaveski@hotmail.com \\ Stefanija Agrotova, MA \\ European Universiity, Skopje \\ E-mail: stefanija.agrotova@eurm.edu.mk
}

\begin{abstract}
:
Instability in Southeastern Europe, and especially in the Balkans as its most vulnerable part, is primarily a European problem, but also a problem for NATO. These countries were included in the regional stabilization program from the very beginning. Twenty-five years later, the truth is that there is no open or visible threat of war and ethnic conflict. However, some security challenges still exist as a seed for a potential crisis. There is still unfinished business in Bosnia and Herzegovina, which threatens to shake ethnic stability. Kosovo struggles for its full independence and promotion as a sovereign state and faces a strong Serbian diplomatic action to oppose the unilaterally proclaimed independence of Kosovo. Macedonia has a name dispute with Greece and waits too long for NATO membership and to begin the negotiation process for EU membership. Serbia as a country is important from many perspectives that are related to regional stability. During the Warhaw Summit it was noted that the Western Balkans is a region that is of strategic importance to which the alliance pays proper attention. Democracy values, the rule of law, domestic reforms and good neighborly relations are of vital importance to regional cooperation. Euro-Atlantic integration of the region was also emphasized in the final communique of the summit. NATO stressed that decisions on enlargement will depend solely on NATO and that each aspirant will be evaluated based on its achievements. In our paper we will analyze regional security challenges and NATO role.
\end{abstract}

Key words: Western Balkans, regional security, enlargment, NATO 


\section{Introduction}

Today's security challenges include a plethora of complex and evolving dangers, including international terrorism, the proliferation of weapons of mass destruction (WMDs), failed states, stalemated but unremitting conflicts, organised crime, cyberthreats, energy shortages, environmental degradation and its associated security risks, natural and man-made disasters, pandemics and many others. Facing these threats effectively will require wide-ranging partnership and strong synergy between NATO and the European Union (EU). The two organisations should take a holistic approach to security issues and work together in the defence domain. Although neither a geographic nor a functional division of labour is a feasible option, it is now accepted in many circles that some forms of outreach, for example peacekeeping in Africa and the Balkans.

The Euro-Atlantic perspective for certain Western Balkan countries has never been more ambiguous since the end of the Cold War. The integration into security organizations, notably into the North Atlantic Treaty Organization (NATO), of the region is a necessity not only for these countries and the promotion of good neighborly relations amongst each other but also for the alliance. The risks and threats that have emerged in the past few years will be a challenge for the Western Europe and the common values they share in the years to come. It is evident that the NATO Alliance has recognized the contemporary threats. Indeed Heads of the States and Governments of the NATO member states had a full agenda of topics for conversation during the Summit in Warsaw on 8-9 July 2016. ${ }^{3}$ The focus was on reviewing the accomplishments of the NATO Strategic Concept adopted in 2010 and the decision for strengthening the defense dimension of NATO decided during the last summit in Cardiff in 2014. However, during the Summit, the leaders noted that the security environment changed since the last high-level meeting. Thus, it necessitated additional measures to ensure the security of the Allies. ${ }^{4}$

NATO asked the Member States during the Welsh Summit to invest in defense at least $2 \%$ of their national budgets. However, what matters for the Alliance was also how the money allocated for defense would be provided; i.e., at least 20 percent of the defense budget to be for the procurement of new equipment, including funds for research

\footnotetext{
3 Warsaw Summit Communiqué Press Release (2016) 100 Issued on 09 Jul. 2016. http://www. nato.int/cps/en/natohq/official_texts_133169.htm\#piracy (accessed: 15.11.2016).

${ }^{4}$ For example, even if France did not invoke Article 5 of the Washington Treaty, there was a consensus among the members that the terrorist attacks in Paris in November 2015 were acts of armed aggression. Since 2010, the terrorist group Islamic State (IS), along with al-Qaeda, is considered a NATO enemy. Moreover, NATO agreed that hackers' attacks could, under certain conditions, be considered as an act of aggression to be followed by a response under Article 5 of the Washington Treaty.
} 
and development. So, a number of Member States halted the subsequent reductions in military expenditures that were made in the years before the Welsh Summit and, in some cases, the process of increasing military spending started. It is too early to say how increased funds for defense will be used. This debate is one of the most contentious within NATO. There are complaints that Europe spends too little on defense and is protected at the expense of the taxpayers of the United States. However, the imbalance is not as great as it is sometimes suggested. The Warsaw Summit concluded that military spending by European members of NATO is no longer declining, but it is actually increasing. Nevertheless, convincing the taxpayers of Europe to make significant increases in defense spending remains a serious challenge. In addition, in light of the complex security challenges that need to be resolved, whether increasing military spending is always the most appropriate response to the threats remains as open question.

\section{NATO - Russia Relations}

The current NATO Strategic Concept of 2010 emphasized that there were low attack threats against NATO but highlighted the strategic importance of cooperation with Russia. However, NATO today, no longer sees Moscow as a partner. Relations between Russia, NATO and the West have generally deteriorated. Since the illegal Russia annexation of Crimea, NATO has suspended all practical, civilian and military forms of cooperation with Russia, leaving only some channels open for dialogue. In a television interview in Poland in May 2016, NATO Secretary General, Jan Stoltenberg said that the best option for NATO is to avoid the escalation of bad relations with Moscow and to try to establish an open dialogue. NATO-Russia Council met in April 2016, but Stoltenberg pointed out that this encounter had been only due to the existence of deep disagreements. ${ }^{5}$

In accordance with the prevailing activities, NAT0 and Russia agreed in 1997 that a permanent stationing of substantial combat forces in Central and Eastern Europe was not necessary. Some NATO members now believe that the security environment has significantly changed, and this agreement should no longer be in force. In addition, during the Welsh summit, it was decided to increase the number of military exercises conducted each year and new military exercises with scenarios of collective defense to be designed. ${ }^{6}$ The United States were undertaking measures to strengthen the forces of the NATO eastern wing by maintaining significant rotational forces with wider members' participation.

\footnotetext{
${ }^{5}$ Relations with Russia 27 0ct. 2016 NAT0. http://www.nato.int/cps/en/natolive/topics_50090. htm (accessed: 08.10.2016).

${ }^{6}$ In 2016 there were 23 military exercises with these scenarios that involved 20 different nations. For example, in March 2014, Poland requested 10,000 troops from NAT0 to be deployed at military bases in its territory, but the Alliance did not respond positively to this request.
} 
Implementation of a number of measures related to strengthening of the common collective defense, which has been agreed by the leaders during the previous summit in Wales in 2014, have been discussed at the Warsaw Summit. Many so called "security measures" were agreed at the Summit, including the continued air, land and sea presence, as well as the conduct of significant military activities in the eastern part of the Alliance. Plans were made to ensure that about 4,000 soldiers from NAT0 countries, on a rotational basis, will be deployed in the Baltic States and Poland. These forces were created to respond immediately and wherever Alliance finds there is a need. In addition it was agreed that the NATO response would be doubled, to 40,000 soldiers.

An important segment of the discussions between the NATO leaders was how to respond to Russian tactics pointing to how this is closely linked to national perceptions about security problems and which military response is appropriate. The model of the nuclear deterrent is becoming more popular in European security and was part of the leaders' discussion. Statements by some senior Russian leaders have focused the attention of the Alliance to how Russia will use its nuclear weapons, which according to the military doctrine is part of all scenarios of Russian military exercises. NATO did not make significant modifications to nuclear policies at the Warsaw summit, but agreed specific solutions for better integration of conventional and nuclear forces of the Alliance. Russia has already carried out military exercises in which nuclear forces were closely integrated with conventional ones. In addition to the USA, NATO, France and the UK also have nuclear facilities, and in the Communique they reminded Russia that, if needed, their facilities would be available to NATO.

In 2010, NAT0 was given powers by the governments of Member States to organize the antimissile defense of their territory; i.e., for equal protection of the European countries of the Alliance in case of attack from short or medium range ballistic missiles. Implementation of the decisions from 2010 was also reviewed during the Warsaw Summit. Until now the US and NATO have developed missile defense programs that are not directed against Russia, but such an option is not excluded in the future.

\section{NATO and EU cooperation in the Western Balkans}

The enlargement of the European Union and the North Atlantic Treaty Organization are seen as beneficial both by bringing stability and security and introducing democratic and economic reforms. Both organisations have supported the Western Balkan countries in their respective processes of post-authoritarian democratisation, transition to market economies, and of post-conflict reconstruction. The enlargement perspective has played and continues to play a crucial role in the regional stabilisation and pacification processes. 
One example of successful security-related cooperation between NATO and the European Union was the Ohrid Framework Agreement to prevent war in the Republic of Macedonia. In February 2001, at the height of inter-ethnic strife between the country's security forces and armed Albanian insurgents, NATO and the European Union coordinated the negotiations that led to the Ohrid Agreement in August of that year. Then, to reduce the possibility of backsliding, NATO agreed to continue its support with Operation Allied Harmony, conducted from December 2002 to March the next year, at which point the operation was handed over to the European Union. In late March 2003, the European Union launched its first-ever peacekeeping mission, Operation Concordia, which was also the first implementation of the Berlin Plus agreement. A small NATO headquarters remained in Skopje to assist the country's authorities in the development of securitysector reform and adaptation to NATO standards. The European Union maintained Operation Concordia until December 2003, and followed up with a civilian police mission, Operation Proxima, which continued through the end of 2005.

Another positive example is Bosnia and Herzegovina. In December 2004, NAT0 terminated its nine-year Implementation Force (IFOR)/Stabilisation Force (SFOR) operation, and handed it over to the European Union, which immediately began its 6000 -strong Operation Althea. As in the operations in the Republic of Macedonia, NATO's Deputy Supreme Allied Commander Europe (DSACEUR) was named Operational Commander, acting under political guidance and direction of the European Union's Political and Security Committee (PSC). NATO maintains a modest headquarters in Sarajevo to assist Bosnia and Herzegovina's authorities with defence reform, handle certain operational tasks involving counter-terrorism and detention of persons indicted for war crimes, as well as intelligence-coordination with the EU Force (EUFOR).

NATO should consider a more flexible policy and strive to deter prospective adversaries with a wide range of instruments. By partnering with the EU and expanding its set of instruments, the Alliance will be able to tackle the threat from multiple angles. What is more, it may be even able to prevent it. The EU seems the organisation best suited to complement NATO's crisis management efforts, as it offers a diversity of instruments that can be employed in hybrid warfare. NATO and the EU could create an effective institutional tandem that has a wide range of both political and military instruments at its disposal. ${ }^{7}$ The NATO Summit in Warshaw acknowledged the EU as a strategic partner of the Alliance. And the common threat of hybrid warfare within the Euro-Atlantic area presents a solid opportunity to develop this partnership even further. NATO and the EU should intensify consultations and engage in joint planning and inter-institutional cooperation should become more systematic and pragmatic.

${ }^{7}$ European Neighbourhood Policy and Enlargement Negotiations. December 6, 2016 https:// ec.europa.eu/neighbourhood-enlargement/ (accessed: 02.01. 2017). 


\section{NATO and the Western Balkans}

The political and the security environment in the Western Balkans is an issue that will be of concern for Europe as a whole but also for NATO. The Balkan countries have been impacted by the consequences of the end of the Cold War with the dissolution of Yugoslavia. Although war broke out and the former Republics gained independence from Yugoslavia, there still is an unfinished business in the region.

Instability in Southeastern Europe, and especially in the Balkan as the most vulnerable part, is primarily a European problem, but also a problem for NATO and the United States. These countries were included in regional stabilization from the very beginning. Twenty-five years later, the truth is that there is no open or visible threat of war and ethnic conflict. However, some security challenges still exist as a seed for a potential crisis. There is still unfinished business in Bosnia and Herzegovina, which threatens to shake ethnic stability. Kosovo struggles for its full independence and promotion as a sovereign state and faces a strong Serbian diplomatic action to oppose the unilaterally proclaimed independence of Kosovo. Macedonia has a name dispute with Greece and waits too long for NATO membership and to begin the negotiation process for EU membership. Serbia as a country is important from many perspectives that are related to regional stability.

For many years, it also appeared that progress was being made. All countries in the region had become members of the Alliance's Partnership for Peace (PfP) after Bosnia and Herzegovina, Montenegro and Serbia joined in December 2006. However, Kosovo, which had not declared independence at the time, is still not a member of PfP. Albania and Croatia joined NATO in 2009 and Montenegro was invited to join in December 2015. Republic of Macedonia has been part of NATO's Membership Action Plan (MAP) since 1999. And Bosnia and Herzegovina was invited to join the MAP in 2010, though its activation was made conditional on the resolution of a key issue concerning immovable defence property (this is still pending though progress has been made). ${ }^{8}$

The processes of European and Euro-Atlantic integration certainly contributed greatly to supporting reforms and building stability in countries that joined the European Union and NATO from Central and Eastern Europe. However, they were designed to assist accession to international institutions, not to manage conflict. Whereas the European Union and the United States kept a tight control on developments in South Eastern Europe in the second half of the 1990s and the early years of the new millennium,

${ }^{8}$ Croatia joined the European Union in 2013. Albania, Republic of Macedonia, Montenegro and Serbia are EU candidate states. Bosnia and Herzegovina and Kosovo have both signed Stabilisation and Association Agreements with the European Union. And Bosnia and Herzegovina formally submitted an EU membership application in February 2016. 


\section{Security}

they subsequently downgraded their engagement to focus on more pressing conflicts elsewhere in the world. Moreover, the chances of leveraging the desire of the majority of the region's population for closer links to Western Europe to fundamental change depend, above all, on the prospect of eventual membership being real. As the European Union has become increasingly embroiled in internal matters - the sovereign debt crisis, responding to an unprecedented influx of migrants and Brexit - that prospect has also faded. As a result, reform processes have stalled, increasingly authoritarian elites have entrenched themselves in power, and irredentism has returned to the political agenda. ${ }^{9}$

During the Summit in Warhaw it was noted that the Western Balkans is a region that is of strategic importance to which the alliance pays proper attention. Democracy values, the rule of law, domestic reforms and good neighborly relations are of vital importance to regional cooperation. Euro-Atlantic integration of the region was also emphasized in the final communique of the summit. NATO stressed that decisions on enlargement will depend solely on NATO and that each aspirant will be evaluated based on its achievements.

With regard to Serbia which though with no aspirations for membership, is a partner country, NATO has stressed the importance of "dialogue between Pristina and Belgrade" that EU facilitates and has encouraged both countries to implement agreements. On 24 January 2016, the European Union convened a meeting of Prime Ministers and Presidents in the framework of its Belgrade-Pristina Dialogue to try and rebuild confidence in the EU-led process aimed at normalising relations between Serbia and Kosovo. ${ }^{10}$

In this respect, the efforts of the Kosovo authorities to provide "safety and security for all its citizens" were welcomed. A new Kosovo Court, the Specialist Chambers and Specialist Prosecutor's Office, with jurisdiction over certain crimes against humanity, war crimes and other crimes, which allegedly occurred between 1 January 1998 and 31 December 2000, became operational on 1 January. However Kosovo has no contractual relationship with NATO mainly due to four NATO member states that are non- recognizers (Spain, Rumania, Slovakia, and Greece).

Relations between Bosnia and Herzegovina $(\mathrm{BiH})$ and NATO have a very interesting history since the end of the Cold War which includes the NATO intervention through postDayton "to impose peace," "missions to maintain peace," defense reform and assisting BiH's aspirations for NATO membership. The complex internal structure and political system burdens the processes between BiH and NATO. As a country it has two distinct

\footnotetext{
${ }^{9}$ Christopher Bennett, (2017) "Backsliding in the Western Balkans" in NATO Review Magazine.

10 "Serbian train sparks escalation in tensions with Kosovo". BBC News Services. January 14, 2017. http://www.bbc.com/news/world-europe-38625872 (accessed: 02.02.2017).
} 
entities that reflect the different strategic approaches from interested international actors in the region. Since 2008, there have been new policies and the impact of global actors has become more visible and has led to a change in the relations among the internal actors in BiH. However, according to an official standpoint, the strategic goals for NATO membership have not changed. On the one hand, internally, the components of the Federation define their strategies, which express their varying interests. On the other hand, the institutional, international community exists as the strongest actor in the internal processes as part of the peace process in BiH. However, the real impact of 1995 and the beginning of the peace process have changed, reflecting the ambiguity in the relationships between local players. Because of unresolved key internal relations, the process of democratization and efficiency of institutions in BiH are at stake. All this produces an uncertain atmosphere that is not an appropriate environment to a strategic approach to NATO. ${ }^{11}$ The problem of Bosnia and Herzegovina is that the Serbian entity in the state is skeptical of NATO membership. ${ }^{12}$ In this context, political will by the leaders in Bosnia and Herzegovina is required to demonstrate support for NATO membership. Hence, the progress made for the registration of real military property of the state to allow the country to deliver the promise made at the meeting of the foreign ministers of NATO member states held in Tallinn in April 2010 is welcomed, which is to activate the first cycle of the Membership Action Plan.

Bosnia and Herzegovina has to face painful reforms in the defense sector. Macedonia has met the criteria for membership since 2008. The only problem then was the resolution of the "name dispute" with Greece. Meanwhile Macedonia has received two additional conditions. Albania imposed the issue of "full implementation of the Framework agreement", whatever that means, and Bulgaria the signing of the agreement on "good neighborly relations". ${ }^{13}$ During the Warsaw Summit, Macedonia received another condition, resolving the political crisis and the rule of law as a condition for integration in the Alliance. As things stand, Macedonia, rather than closer to NATO, is getting farther away from NATO membership and has been reflected in the decrease of public support for NATO membership. In addition, it has been reiterated that the invitation will be delivered to the Republic of Macedonia as soon as a mutually acceptable solution with Greece over

\footnotetext{
${ }^{11}$ The United States imposed sanctions on Dodik on 17 January for obstructing the Dayton Peace Agreement.

12 "Dodik accuses NATO of interfering in Bosnia's internal matters" Europe Balkan News. January 08,2017 . https://eblnews.com/news/balkan/dodik-accuses-nato-interfering-bosnias-internal-matters-51198 (accessed: 02.03.2017).

${ }^{13}$ Warsaw Summit Communiqué Press Release (2016) 100 Issued on 09 Jul. 2016. http://www. nato.int/cps/en/natohq/official_texts_133169.htm\#piracy (accessed: 15.11.2016).
} 
the "name issue" within the UN is reached. In addition to requiring an early solution to the dispute with Greece, further efforts to develop good neighborly relations are required. Macedonia should also build a functional multi-ethnic society and fully implement the Ohrid Framework Agreement. What is new is that the Alliance is concerned about political developments that further push the country away from NATO values. In this sense a full implementation of the Przino's Treaty is necessary as a framework for a sustainable solution to the political crisis in the country. ${ }^{14}$ Now all parties involved in the process are required strengthening the rule of law, free media and an independent judiciary. Regarding the cuurent political crisis NATO Segretary General Jens Stoltenberg emphasizes that NATO has an interest in "upholding... the political values and principles upon which the alliance is based" and urged political leaders in Skopje to take the necessary steps to form a government quickly. ${ }^{15}$

In May 2016 Montenegro signed a protocol of accession. This protocol is being reviewed by the Member States in accordance with their national procedures after which Montenegro will become the 29th member of NATO. However, according to the Government of Montenegro data, the opinion poll towards NATO accession support is still low. The survey that took place in January 2016 notes that $47.3 \%$ of the citizens of Montenegro support the country's membership in NAT0, 37.1\% oppose and 15,6 of them are undecided. ${ }^{16}$ Pending the completion of the ratification procedure Montenegro is expected to continue with the reform process and to strengthen its contribution to the security of the Alliance. After the joining of Bulgaria, Romania and Slovenia in 2004 and Albania and Croatia in 2009, the decision on NATO membership for Montenegro is a step towards the consolidation of Southeast Europe. The decision is also a signal that NATO enlargement is not frozen and that the doors are open for Macedonia and Bosnia and Herzegovina in the future. However in NATO there is a consensus that in the short term possibilities for further enlargement of the Alliance are limited.

Moreover, the international peacekeeping forces - KFOR in Kosovo, which has 4,300 troops, and EUFOR in Bosnia, which has 600 soldiers - have mandates and contingency plans to maintain a safe and secure environment. Nevertheless, an increasingly tense situation has to be monitored closely, greater diplomatic attention must be focused on

\footnotetext{
${ }^{14}$ In the Republic of Macedonia, EU and US negotiators facilitated an agreement between political parties which led to early elections in December 2016.

${ }^{15}$ http://balkanist.net/nato-chief-pledges-the-alliance-has-no-interest-in-macedonias-internal-political-process/

${ }^{16}$ Government of Montenegro. "Latest opinion poll: $47.3 \%$ of citizens support Montenegro's NATO accession" 01.02. 2016 http://www.gov.me/en/News/157178/Latest-opinion-poll-47-3-of-citizens-support-Montenegro-s-NATOaccession. html (accessed: 20.10.2016).
} 
the region and new strategies developed to address the many outstanding issues. ${ }^{17}$ In order to strengthen the southern flank NATO must continue with the implementation of the open door policy even after the accession of Montenegro. Macedonia and Bosnia and Herzegovina should sooner rather than later be encouraged to join the Alliance.

\section{Conclusion}

Having in mind the complex geopolitical situation in the Western Balkans, the Euro-Atlantic institutions must step in sooner rather than later in order to provide a clear strategic message and provide membership and integration prospect to those countries in the region. It would make it clear also to other actors which are interfering in every occasion and opportunity that can be found in the region. Acknowledge that closer cooperation and integration with NATO requires more research on the specific requirements on each country. Therefore, harmonize and prioritize the policies and projects with regional initiatives in regards to institutional capacity building in the Western Balkans and therefore avoid overlapping. NATO must help and fast track the integration of the remaining Western Balkan countries into its umbrella before the region slips away in dismay. Interfering right in the NATO's and EU's back yard, Russia is expanding its sphere of influence creating ambiguity amongst the countries that are already confused about their place in the midst of the global crisis. ${ }^{18} \mathrm{~A}$ swift integration of the region into NATO means that the new members could continue their democratic reforms and economic developments while inside the realm of the Euro-Atlantic institutions as the future is clearer rather than adding more requirements to the pre-membership list which in turn would provide opportunities for other stakeholders to impact the process.

NATO should keep the enlargement policy alive by supporting the aspirant countries from the Western Balkans with concrete measures to encourage reforms in this region. In addition, a suggestion to readdress the open door policy in the Western Balkans, with an alternative decision making process, clearer provisions for Macedonia, Bosnia and Kosovo. That will give incentives to achieve successful reforms, utilize the momentum to speed up domestic reforms. On the other side politicians from the region should strengthen cooperation in political and security area. They should show more dedication to common goals and take over ownership of the processes so they are easier to implement rather than have imposed processes. In that regard set real and achievable goals, being aware that domestic reforms should be conducted for the sake of the countries, not for other's sake.

\footnotetext{
${ }^{17}$ Christopher Bennett, (2017) "Backsliding in the Western Balkans" in NATO Review Magazine.

${ }^{18}$ Pivovarenko, Alexander, "Modern Russia in the Modern Balkans: Soft Power through Investment" Russian International Affairs Council May 23, 2014. http://russiancouncil.ru/en/inner/?id_4=3744 (accessed: 02.01.2017).
} 


\section{Seccurity}

\section{References}

- Bennett Christopher (2017), "Backsliding in the Western Balkans", NAT0 Review Magazine.

- "Dodik accuses NATO of interfering in Bosnia's internal matters", Europe Balkan News, January 08, 2017. https://eblnews.com/news/balkan/dodik-accuses-natointerfering-bosnias-internal-matters-51198 (accessed: 02.03.2017).

- European Neighbourhood Policy and Enlargement Negotiations. December 6, 2016 accessed https://ec.europa.eu/neighbourhood-enlargement/ (: 02.01. 2017).

- "Latest opinion poll: 47.3\% of citizens support Montenegro's NATO accession" 01.02. 2016, accessed http://cherna.gora.me/government/latest-opinion-poll47-3-of-citizens-support-montenegros-nato-accession/.

- Pivovarenko, Alexander. "Modern Russia in the Modern Balkans: Soft Power through Investment" Russian International Affairs Council May 23, 2014, accessed on: http://russiancouncil.ru/en/inner/?id_4=3744.

- Relations with Russia 27 0ct. 2016 NATO, accessed on: http://www.nato.int/cps/ en/natolive/topics_50090.htm.

- "Serbian train sparks escalation in tensions with Kosovo". BBC News Services. January 14, 2017. http://www.bbc.com/news/world-europe-38625872 (accessed: 02.02.2017). Warsaw Summit Communiqué Press Release (2016) 100, issued on 09 Jul. 2016, accessed on: http://www.nato.int/cps/en/natohq/official_ texts_133169.htm\#piracy. 